\title{
Preliminary assessment of large mammals in the Namcha Barwa region of south-eastern Tibet
}

\author{
Qiu Ming Jiang and William V. Bleisch
}

\begin{abstract}
In 1994 the authors made two rapid assessments of wildlife in the remote Namcha Barwa region, south-eastern Tibet, China. They conducted interviews, examined and recorded trophies in the possession of local Menba, Luoba and Kangba Tibetans and made opportunistic field observations. Despite the extensive forests in this extremely remote region, wildlife populations appeared to be low except in inaccessible areas along county borders. Frequent reports of tiger predation on cattle, horses and mules in glaciated valleys on the south slope of the Himalayas may indicate a shortage of natural prey. Uncontrolled hunting, human population growth and expedient economic development threaten the survival of large mammals in the region.
\end{abstract}

\section{Habitat}

The Namcha Barwa region lies within the Linzhi District in the south-east of the Xizang (Tibetan) Autonomous Region in China (Figure 1). Zoogeographically, it lies at the junction of the Eastern Himalayas, the Qinghai-Xizang Plateau, the Hengduan Mountains and the Assam Region (Zhang et al., 1982). The Yarlung Tsangpo River (the Brahmaputra in India) runs from west to east, cutting through a range of high mountains dominated by Namcha Barwa $(7782 \mathrm{~m})$ and Jala Beri $(7151 \mathrm{~m})$. The river bends sharply south around Namcha Barwa and flows rapidly down to the Assam Plains in India. In the process, the river creates the world's deepest canyon (Anon., 1994). Within $45 \mathrm{~km}$ the depth of the gorge spans $700 \mathrm{~m}$ at Beibeng to over $7000 \mathrm{~m}$ (Figure 1).

The region has a monsoon climate, which provides excellent growing conditions for forests. The annual average rainfall is 1000-3000 mm (Editorial Board of the Chinese Geographic Series, 1990). Some of China's best old-growth forests, both in term of species composition and forest productivity, remain here (Xu Fengxiang, pers. comm.).

The vertical zonation of habitats is dramatic. Tropical monsoon forest is found between 560 and $1100 \mathrm{~m}$ and has a diverse flora, character- ized by Terminalia myriocarpa, Lagerstroemia minuticarpa, Garcinia morella, Sloanea sinensis, Fissistigma oldhamii and other broadleaved evergreen species. The trees Alingia sp., Actinodaphne lancifolia and Cryptocarya chinensis form an understorey. Between 1100 and $2500 \mathrm{~m}$ there are well-developed subtropical, montane, broadleaved forests, containing oak Quercus tungmaiensis and evergreen chinkapins Castanopsis xizangensis and C. lamellosa. Alder Alnus nepalensis and birch Betula utilis dominate the lower slopes and valley bottoms. From 2500 to $3000 \mathrm{~m}$, the forest consists of Yunnan pine Pinus yunnanensis, hemlock Tsuga dumosa and spruce Picea likiangensis. From 3000 to $3700 \mathrm{~m}$, the fir, Abies delavayi, predominates. Alpine shrub covers the slopes between 3700 and $4000 \mathrm{~m}$ and the tree-line may extend up to $4200 \mathrm{~m}$, depending on local topographical and edaphic conditions. The upper forest limit is fringed by many rhododendron species. Alpine meadows, bare rocks and permanent snow occupy the higher elevations.

Complex topography has resulted in varied vegetation and uneven wildlife distributions. For example, west and north-west of Xiejian La (la means mountain pass in Tibetan), the coniferous forest ends at $2900 \mathrm{~m}$. However, on southern slopes in Seqi La Mountains, conifers extend as high as $4200 \mathrm{~m}$. South and south- 


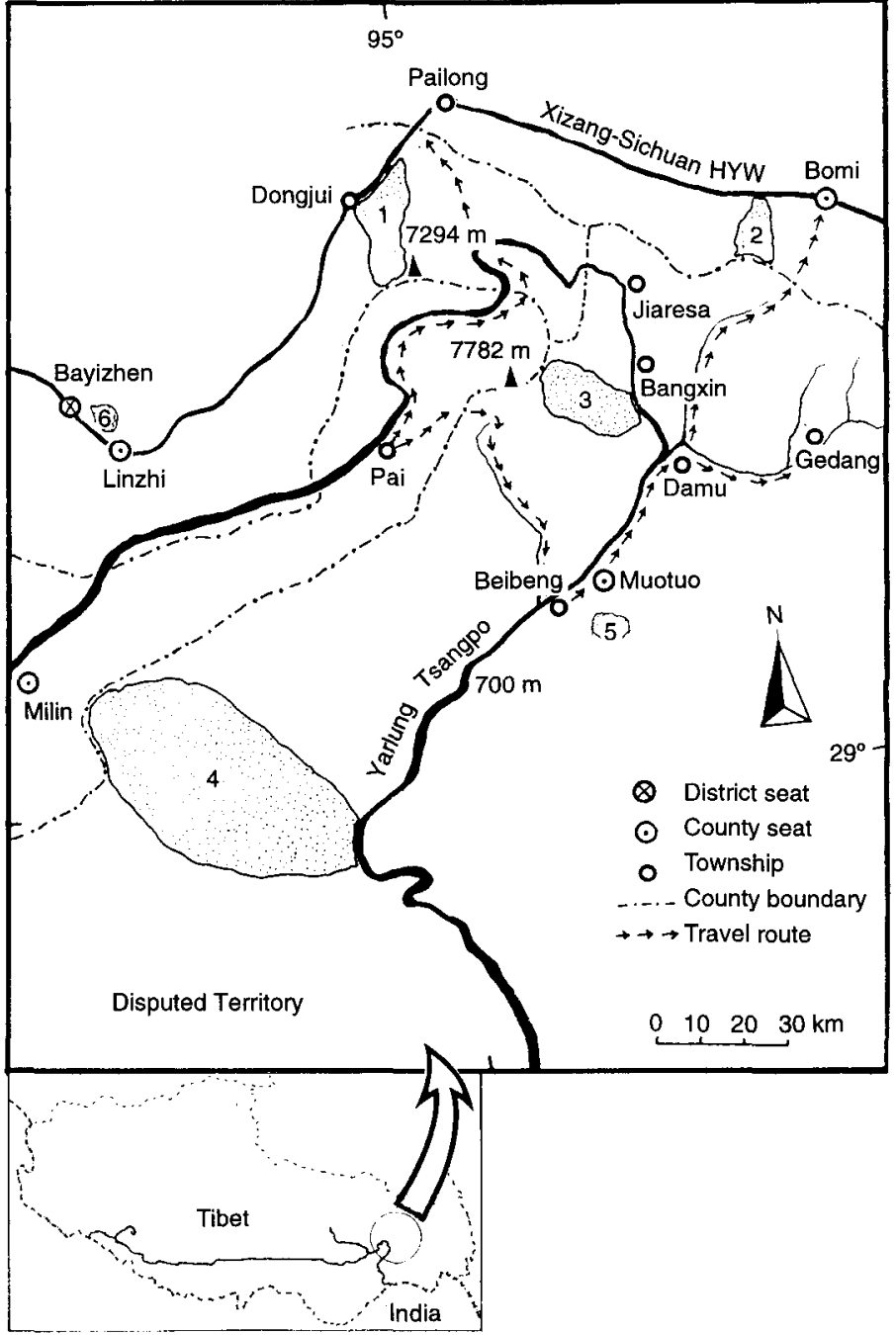

Figure 1. The Namcha Barwa region. Shaded areas indicate protected areas. 1, Dongjiu Red Goral Reserve; 2, Bomi Gangxiang Nature Reserve; 3 , Niela Tsangpo Protected Area; 4 Deyanggou Takin Protected Area; 5, Buqiong Lake Protected Scenic Spot; 6, Bajie Giant Cypress Cupressus gigantea Protected Spot (based on Liu, 1993; Yin and Liu, 1993). west of the Xiejian La, the fauna is dominated by Oriental species (Cai and Zhang, 1980; Feng et al., 1980; Du and Xi, 1993), while Palaearctic elements increase sharply north and north-west of the range. The northern limit of tropical Asian fauna lies further south, towards the disputed border between India and China.

Early western explorers described the abundant and diverse animals and plants in the region (e.g. Ward, 1930; Bailey, 1957). Many of the mammal and bird species still occur but their survival is threatened. Among them, 31 species - including tiger Panthera tigris, leopard $P$. pardus, clouded leopard Neofelis nebulosa, snow leopard Uncia uncia, takin Budorcas taxicolor and red goral Nemorhaedus baileyi - are on Schedule I of China's protected wildlife. An additional 65 species are on Schedule II (Yin and Liu, 1993). Table 1 lists the major protected mammal species in the region.

\section{Methods}

The authors made two assessments of wildlife in the Namcha Barwa region, between 22 April and 27 May and between. 22 September and 13 October, 1994 (Figure 1). Local Menba,

(C) $1996 \mathrm{FFI}$, Oryx, 30 (1), 37-44 
Finger-like projections of tropical and subtropical forests along the Yarlung Tsangpo (Ming Jiang Qiii).

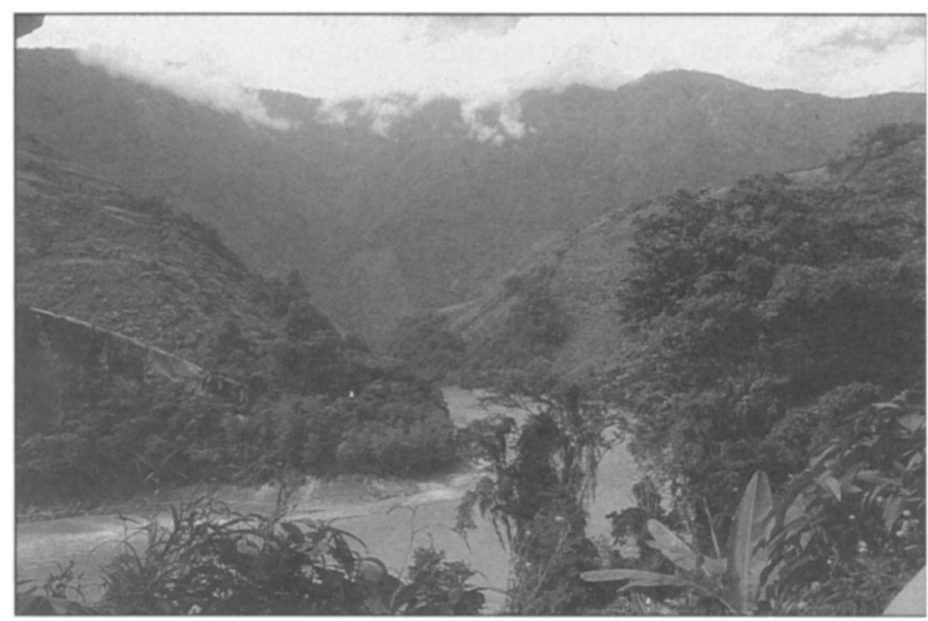

Table 1. Major protected mammal species in the Namcha Barwa region, south-eastern Tibet

\begin{tabular}{|c|c|c|c|}
\hline English name & Scientific name & Chinese list & IUCN list \\
\hline Assam macaque & Macaca assamensis & $\mathrm{I}$ & - \\
\hline Rhesus monkey & Macaca mulata & II & - \\
\hline Hanuman langur & Semnopithecus entellus & II & - \\
\hline Dhole & Cuon alpinus & II & $\mathrm{V}$ \\
\hline Asiatic black bear & Ursus thibetanus & II & $\mathrm{V}$ \\
\hline Brown bear & Ursus arctos & III & - \\
\hline Lesser panda & Ailurus fulgens & II & $\mathrm{V}$ \\
\hline Eurasian otter & Lutra lutra & II & - \\
\hline Small-clawed otter & Anoyx cinerea & II & K \\
\hline Large Indian civet & Viverra zibetha & II & - \\
\hline Small Indian civet & Viverricula indica & II & - \\
\hline Spotted linsang & Prionodon pardicolor & II & - \\
\hline Yellow-throated marten & Martes flavigula & II & - \\
\hline Tiger & Panthera tigris & $\mathrm{I}$ & $\mathrm{E}$ \\
\hline Leopard & Panthera pardus & $\mathrm{I}$ & - \\
\hline Clouded leopard & Neofelis nebulosa & $\mathrm{I}$ & $\mathrm{V}$ \\
\hline Snow leopard & Uncia uncia & $\mathrm{I}$ & $\mathrm{E}$ \\
\hline Golden cat & Felis temmincki & II & $\mathrm{I}$ \\
\hline Jungle cat & Felis chaus & II & - \\
\hline Southern musk deer & Moschus sifanicus & II & - \\
\hline Forest musk deer & Moschus berezovskii & II & - \\
\hline Black musk deer & Moschus fuscus & II & - \\
\hline Gongshan muntjac & Muntiacus gongshanensis & II & - \\
\hline Red deer & Cervus elaphus subsp? & II & - \\
\hline Blue sheep & Pseudois nayaur & II & - \\
\hline Takin & Budorcas taxicolor & $\mathrm{I}$ & - \\
\hline Goral & Nemorhaedus goral & II & - \\
\hline Red goral & Nemorhaedus baileyi & I & - \\
\hline Serow & Capricornis sumatraensis & II & $\mathrm{I}$ \\
\hline
\end{tabular}

Note: English names follow Tan (1992); scientific names follow Nowak (1991). Chinese Wildlife Law prohibits killing or trapping Class I or Class II species without the Central or Provincial Government's permission, respectively. The IUCN red list definition: E, Endangered, V, Vulnerable, I, Indeterminate and K, Insufficiently known (Groombridge, 1994). 
Luoba and Kangba Tibetan villagers were interviewed; when required, pictures and/or drawings were presented and standard Tibetan names for animals (Feng et al., 1986) were used to enhance communication. A total distance of about $270 \mathrm{~km}$ was walked. The complex topography, dense vegetation (visibility as low as $3 \mathrm{~m}$ ) and mists allowed only opportunistic field observations.

Cliff faces, grassy swards, riversides and other open areas were scanned with $10 \times 30$ binoculars and a $15 \times 45$ telescope. When possible, animals observed were aged and sexed. The altitude of sightings, tracks, feeding sites and other evidence of animal presence were recorded. To assess hunting intensity, fresh trophies in or around village houses along the travel routes were recorded. When a house contained more than one trophy that might have come from the same animal, such as a hide and a skull, they were counted as one animal. Tiger predation was investigated by interviewing county officials and examining feeding sites. Families with heavy losses of livestock were visited to investigate the conflicts between tiger predation and livestock grazing. Forest cover was estimated from $1: 100,000$ scale maps in reference to data published by the Institute of Geography, Chinese Academy of Sciences (1990).

\section{Wild species of conservation concern}

Presence of tiger, leopard, clouded leopard, snow leopard, serow Capricornis sumatraensis, Asiatic black bear Ursus thibetanus, rhesus and Assamese macaques Macaca mulatta and M. assamensis, hanuman langur Semnopithecus entellus, takin, red goral and other animals was confirmed. No large vertebrate species were observed in habitats acessible to humans, which suggests that densities are very low except in the most remote aeas.

\section{Primates}

Macaca assamensis and $M$. mulata were seen briefly in a forest in Milin at about $2700 \mathrm{~m}$ and skins of the former species were frequently found in villagers' homes (Table 2). It was reported consistently that hanuman langurs occur only on the west side of the Yarlung Tsangpo, which may be the eastern limit of this species's distribution. Yin and Liu (1993) reported that the hoolock gibbon Hylobates hoolock is found in southern Motuo, which it was impossible to visit because of restrictions.

\section{Carnivores}

At Jiala (Gyala) on the Yarlung Tsangpo, villagers reported that snow leopard and its main prey, blue sheep Pseudois nayaur, used to occur there at higher altitudes, but have retreated further down the valley because of hunting. At Damu we examined the fur of a young clouded leopard, which had been shot by a local villager. Tiger tracks were found in Gedang, where examination of a kill confirmed a case of tiger predation on livestock. Three black bears were seen, all on the border between Linzhi and Milin, the part of the area that is least accessible to humans.

\section{Ungulates}

Nine herds of takin were seen, a total of 67 individuals, most on the left bank of the Yarlung Tsangpo River. Herd size ranged from one to

Table 2. Number of trophies at village houses along travel routes in Linzhi, Milin, and Motuo counties, southeastern Tibet (22 April-27 May and 22 September-13 October 1994)

\begin{tabular}{lrccccccc}
\hline County & $n$ & Takin & $\begin{array}{l}\text { Red } \\
\text { goral }\end{array}$ & Macaques & $\begin{array}{l}\text { Black } \\
\text { bear }\end{array}$ & $\begin{array}{l}\text { Musk } \\
\text { deer }\end{array}$ & Serow & Muntjac \\
\hline Milin & 2 & 1 & 7 & 1 & 3 & 8 & 2 & 0 \\
Linzhi & 12 & 50 & 18 & 9 & 4 & 7 & 5 & 3 \\
Motuo & 19 & 34 & 6 & 30 & 13 & 2 & 15 & 57 \\
\hline
\end{tabular}


Tibetan porters sitting on takin hides drinking tea during a break (Ming Jiang Qiu).

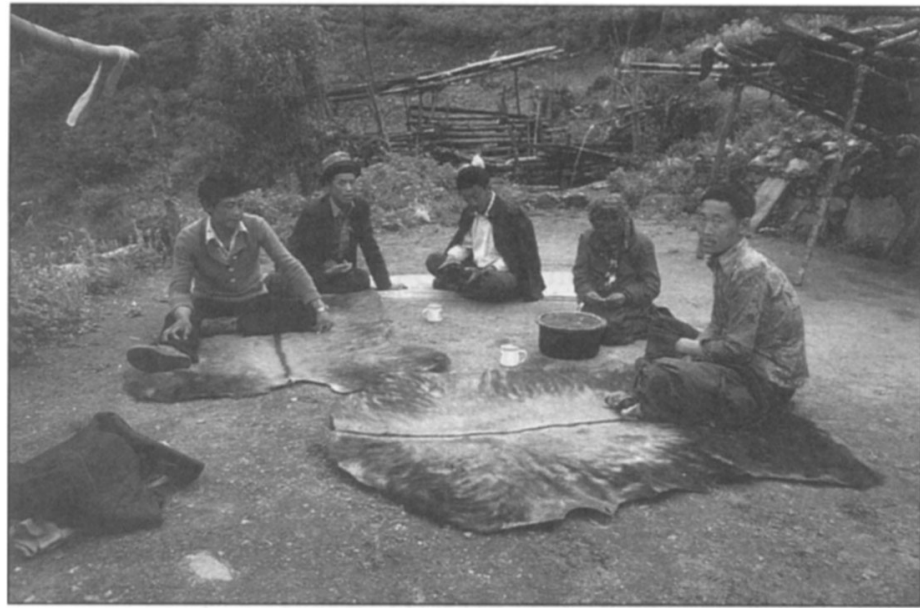

to the upland Tibetans, thus the figures represent minima. The interviews revealed no evidence of arrangements for traditional management of hunting or restriction of hunting areas.

Large mammals, such as takin and red goral, were only found at higher altitudes, although local hunters reported that these animals descend to as low as $1500 \mathrm{~m}$ in winter. Based on sightings and observations of tracks and other signs, the authors estimated a population of about 150-200 takin on the border between Linzhi and Milin, a density in forest habitat of about two animals per sq $\mathrm{km}$. Elsewhere this species, like the red goral, is heavily hunted (Table 2). Two instances may

Table 3. Herd size of takin in Yarlung Tsangpo valley (22 April-27 May 1994)

\section{Hunting and lowland habitat loss: threats to species survival}

Despite the legally protected status of many large mammals in Namcha Barwa, subsistence hunting threatens the survival of large mammals in the region, as indicated by their disappearance in areas with easy access, and in other regions in China (Wu, 1990; Gao et al., 1993; Hu and Wei, 1993; Schaller, 1993). Table 2 summarizes the information on trophies found in village houses along the travel routes. Most trophies observed had been collected by the owners but some skins are sold

\begin{tabular}{lrc}
\hline Herd no. & $\begin{array}{l}\text { No. adults } \\
\text { and subadults }\end{array}$ & No. calves \\
\hline 1 & 10 & 0 \\
2 & 2 & 0 \\
3 & 10 & 0 \\
4 & 6 & 0 \\
5 & 24 & 3 \\
6 & 1 & 0 \\
7 & 8 & 0 \\
8 & 2 & 1 \\
9 & 4 & 1 \\
Totals & 67 & 5 \\
\hline
\end{tabular}


reflect the severity of poaching. In April 1993 the Tibetan porters hired by the authors had taken some Americans into the same area and killed four takin (one adult and three calves) during their 28-day trek. The meat was consumed by the Americans as well as by the porters. A Chinese forest ecologist, $\mathrm{Xu}$ Fengxiang, reported that in April 1994 a porter working for her killed three takin in one day.

Takin calves seemed to suffer heavy losses, judging by the incident described above and by the six young takin hides ( 10.5 per cent of all the trophies) found in and around villagers' homes. The calf : adult and subadult ratio in Nmacha Barwa was only 6.9 per cent compared with the 17.8 per cent reported by $\mathrm{Hu}$ (1994) for takin in northern Sichuan and 14.8 per cent and 21.0 per cent reported by $\mathrm{Wu}$ (1990) and by Song (1994), respectively, for takin in Qinling in central China. The combined effect of poaching and the unusually heavy winter snow in 1993-94 may have taken a significant toll of the young.

Turning forests into pasture in northern Motuo presented a problem for the local Tibetan communities. Although Santiapillai and Ramono (1987) found tiger density to be generally low in mountainous areas, as we did in the steep Yarlung Tsangpo valley, tigers appear to cluster in Namcha Barwa's glaciated valleys, whose flat bottoms provide excellent conditions for grazing. This observation is supported by frequent reports of tiger predation of livestock, which has caused much concern among the local people in Gedang, Bangxin and Jiaresa in northern Motuo. The situation was reported to officials in Lhasa (Pingzhen, pers. comm.). Due to lack of reliable data, however, no action was taken to institute a compensation programme. Between. July 1993 and October 1994, Motuo county reportedly lost 190 cattle, horses and mules. The predation is especially heavy in the Gedang Valley, where local Tibetans pushed grazing land to the upper limit of broadleaved forests. During this 16-month period, Gedang claimed to have lost 141 (10 per cent) of its cattle, horses and mules.

Although leopards Panthera pardus occasionally hunt large mammals such as takin $(\mathrm{Hu}$,
1994) and may even bring down cattle, studies on leopards' and tigers' feeding habits indicate little overlap in the diets of these two predators, with the prey of the former ranging between 25 and $50 \mathrm{~kg}$, and that of the latter species from sambar deer to livestock weighing as much as $450 \mathrm{~kg}$ (Sunquist and Sunquist, 1988). The losses of only large livestock in northern Motuo suggests that the tigers there are losing their food base and may have become accustomed to eating livestock. Loss of lowland habitat and thus the home ranges of tigers increases male-male competition and sometimes produces man-eaters (Sunquist and Sunquist, 1988). Local villagers have reported incidents of tigers mauling people (Liu Wulin, pers. comm.).

Tiger densities decline rapidly when forest, alluvial plains and river basins are cleared or converted to agricultural use (Seidensticker, 1986, cited in Rabinowitz, 1993). No reliable data exist on how many tigers live in the Gedang area. Judging from field observations, however, tiger-human conflict in the Gedang valley will either intensify or the tiger population will decline with further habitat deterioration.

\section{Conclusions}

The Namcha Barwa is one of the world's richest regions in terms of biological diversity. Because of its extreme ruggedness, poor accessibility and relatively low human population density (1.2 humans per sq km; Yin and Liu, 1993), the region still contains some of China's most extensive broadleaved forests and most productive coniferous forests.

Large mammals unique to the Eastern Himalayas, such as takin and red goral, are now found only in extremely remote areas, where their survival is threatened by unmanaged hunting.

The tiger has disappeared from most of its former range in China (see for example, Ma et al., in press). What is perhaps the last viable population of tigers in China survives in the Namcha Barwa region. Loss of lowland habitat and frequent reports of livestock predation 
indicate that this large predator may be short of natural prey, especially in northern Motuo.

\section{Wildlife protection and economic development in the region}

Legal steps towards wildlife conservation were taken in 1983, when the Xizang Autonomous Region Government declared six protected areas. These reserves, however, are too small for effective conservation of large mammals, especially large predators (Figure $1)$.

Long-term plans for developing south-eastern Tibet involve targeting the natural resources of the region (Ding, 1993). As the human population grows and China's economic development gathers speed, extraction of timber resources will accelerate. Depletion of forest resources in western Sichuan and northwest Yunnan provinces is forcing timber operations to move further west (Jiang, 1992). Outdoor activities, such as hiking and sporthunting, have been proposed as attractions for tourism development in the next 10 years (Tibet Tourism Bureau and Shankland Cox, 1990).

In summary, Namcha Barwa is a very important region in China's wildlife conservation system. To preserve the diverse mammalian community requires bringing poaching under control, curtailing further lowland habitat loss and carrying out research to find an integrated solution to problems faced by resource conservation and economic development.

\section{Acknowledgements}

This project is a collaborative effort between the Wildlife Conservation Society and the Conservation Biology Centre of the Kunming Institute of Zoology, Chinese Academy of Sciences. Funds were provided by the Wildlife Conservation Society, the John D. and Catherine T. MacArthur Foundation and the US Bureau of Oceanographic and International Environmental and Science Affairs. The authors wish to thank Ji Weizhi of the Kunming Institute of Zoology and Yin Bingao of the Tibet Forestry Bureau for organizing institutional support. We are grateful to project drivers Cheng Jinhui, Zang Jie and Zhang Boyao, who transported us safely between Kunming and the remote study area. Thanks are extended to Ma Shilai, Han Lianxiang and Zhang Ming for their assistance and companionship in the field. We also would like to thank Zhao Qikun and Richard Harris for critically reviewing the manuscript

\section{References}

Anon. 1994. Mother of all gorges. Asiaweek, January 20.

Bailey, F.M. 1957. No Passport for Tibet. London.

Cai, G.Q. and Zhang, N.Z. 1980. On mammalian fauna in Motuo Region, Xizang. In Symposium Proceedings on Scientific Explorations of QinghaiXizang Plateau (ed. Anon.), pp. 85-86. Chinese Academy of Sciences, Beijing. (In Chinese.)

Ding, Q.F. 1993. The Himalayan Model - a Hypothesis for Future Economic Development on the Qinghai-Xizang Plateau, 1st edn. Xizang People's Press, Lhasa. (In Chinese.)

Du, J.W. and Xi, Y.G. 1993. Avian fauna of Namcha Barwa area. In Scientific Exploration Series on Namcha Barwa Area (ed. Anon.), p. 120. Science Press, Beijing. (In Chinese.)

Editorial Board of the Chinese Geographic Series. 1990. China Atlas of Maps, 1st edn. Chinese Cartographic Press, Beijing. (In Chinese.)

Feng, Z.J., Zheng, C.L. and Cai, G.Q. 1980. Investigation on fauna of southeastern Tibet. In Symposium Proceedings on Scientific Explorations of Qinghai-Xizang Plateau (ed. Anon.), pp. 84-85. (In Chinese.)

Feng, Z.J., Cai, G.Q. and Zheng, C.L. 1986. The Mammals of Xizang, 1st edn. Science Press, Beijing. (In Chinese.)

Gao, Z.X., Ma, J.Z. and Ma, Y.Q. 1993. Historical changes in distribution of northeast China tiger. In The Successional Changes of Mammals in China Under Influences of Human Activities (eds. Xia W. P. and Zhang J.), pp.61-67. China Science and Technology Press, Beijing. (In Chinese.)

Groombridge B. (ed). 1994. 1994 IUCN Red List of Threatened Animals. IUCN, Gland, Switzerland and Cambridge, UK.

Hu, J.C. and Wei, F.W. 1993. The past and present of Sichuan takin. In The Successional Changes of Mammals in China Under Influences of Human Activities (eds. Xia W. P. and Zhang J.), pp. 115-117. China Science and Technology Press. (In Chinese.)

Hu, J.C. 1994. Sichuan's Rare Mammals, 1st edn. Sichuan Science and Technology Press, Chengdu. (In Chinese.)

Institute of Geography, Chinese Academy of 
Sciences. 1990. Atlas of Qinghai and Xizang Plateau 1st edn. Science Press, Beijing. (In Chinese.)

Jiang, Y.X. 1992. Environmental impact and development strategies for western China. In Proceedings of Symposium on Natural Resources and their Development in Western China (ed. Li W. L.), pp. 50-55. The Natural Resources Society of China. (In Chinese.)

Liu, W.L. 1993. Xizang's Nature Reserves. Xizang People's Press, Lhasa. (In Chinese.)

Ma, S.L., Wang, Y.X. and Shi, L.M. 1990. A new species of the genus Muntiacus from Yunnan. Zoological Research, 11 (1), 47-53. (In Chinese.)

Ma, S.L., Han, L.K., Lan, D.Y., Ji, W.Z. and Harris, R.B. In press. Faunal resources of the Gaoligongshan region of Yunnan, China: diverse and threatened. Environmental Conservation.

Nowak, R.M. 1991. Walker's Mammals of the World, 5th edn., Vols I and II. The Johns Hopkins University Press, Baltimore and London.

Rabinowitz, A. 1993. Estimating the Indochinese tiger Panthera tigris corbetti population in Thailand. Biological Conservation, 65, 213-217.

Santiapillai, C. and Ramono, W.S. 1987. Tiger numbers and habitat evaluation in Indonesia. In Tigers of the World, pp. 85-92. Noyes Publications, New Jersey.

Schaller, G.B. 1993. The Last Panda, 1st edn. The University of Chicago Press, Chicago.

Shi, L.M. and Ma, C.X. 1988. A new karyotype of muntjac (Muntiacus sp.) from Gongshan county in China. Zoological Research, 9,343-347. (In Chinese.)

Song, Y.L. 1994. Present population status and con- servation of the golden takin in the Shaanxi Foping National Reserve, China. Tigerpaper, 21 (4), 9-12.

Sunquist, F. and Sunquist, M. 1988. Tiger Moon. The University of Chicago Press, Chicago and London.

Tan, B.J. 1992. A Systematic List of Mammals, 1st edn. Chinese Pharmaceutical Science and Technology Press, Beijing. (In Chinese)

Tibet Tourism Bureau and Shankland Cox. 1990. Tourism Plan for Tibet Autonomous Region Working Report for the People's Government of Tibet Autonomous Region. China National Tourism Administration, United Nation Development Program, and World Tourism Organization. Business Press, Shanghai. (In Chinese.)

Ward. K. 1930. Plant Hunting on the Edge of the World. Cadogan Books, London.

Wu, J.Y. 1990. The Chinese Takin. China Forestry Publishing House, Beijing.

Yin, B.G. and Liu, W.L. 1993. Tibetan Wildlife and Their Conservation, 1st edn. Chinese Forestry Press, Beijing. (In Chinese.)

Zhang, R.Z., Zheng, D. and Yang, Q.Y. 1982. The Physical Geography of Xizang, 1st edn. Science Press, Beijing. (In Chinese.)

Ming Jiang Qiu, Kunming Institute of Zoology, Kunming, Yunnan 650223, People's Republic of China.

William Bleisch, Wildlife Conservation Society, The Bronx, NY 10460, USA. 